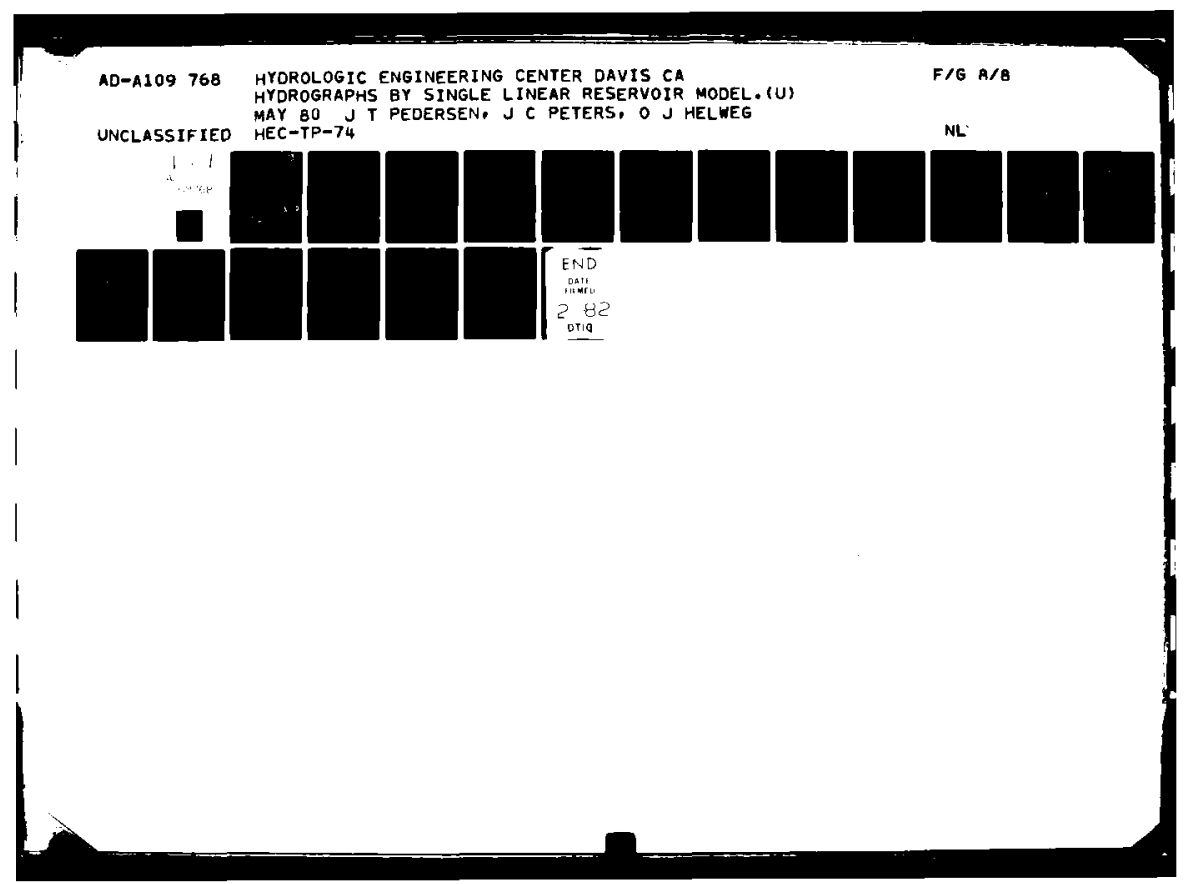




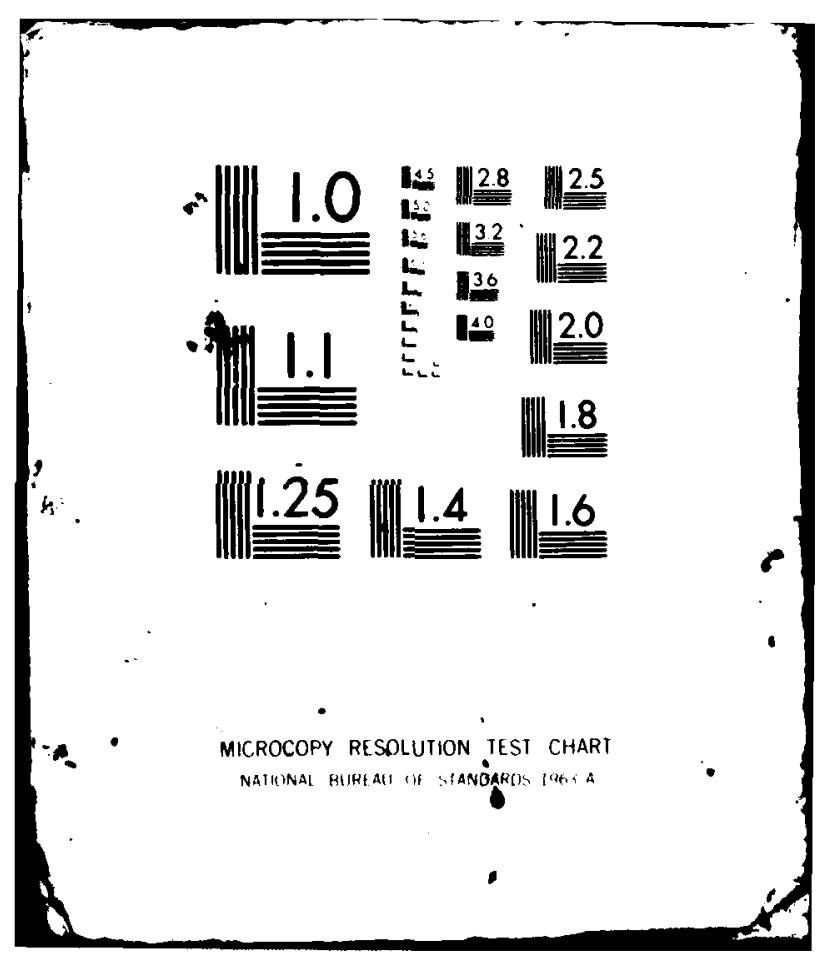




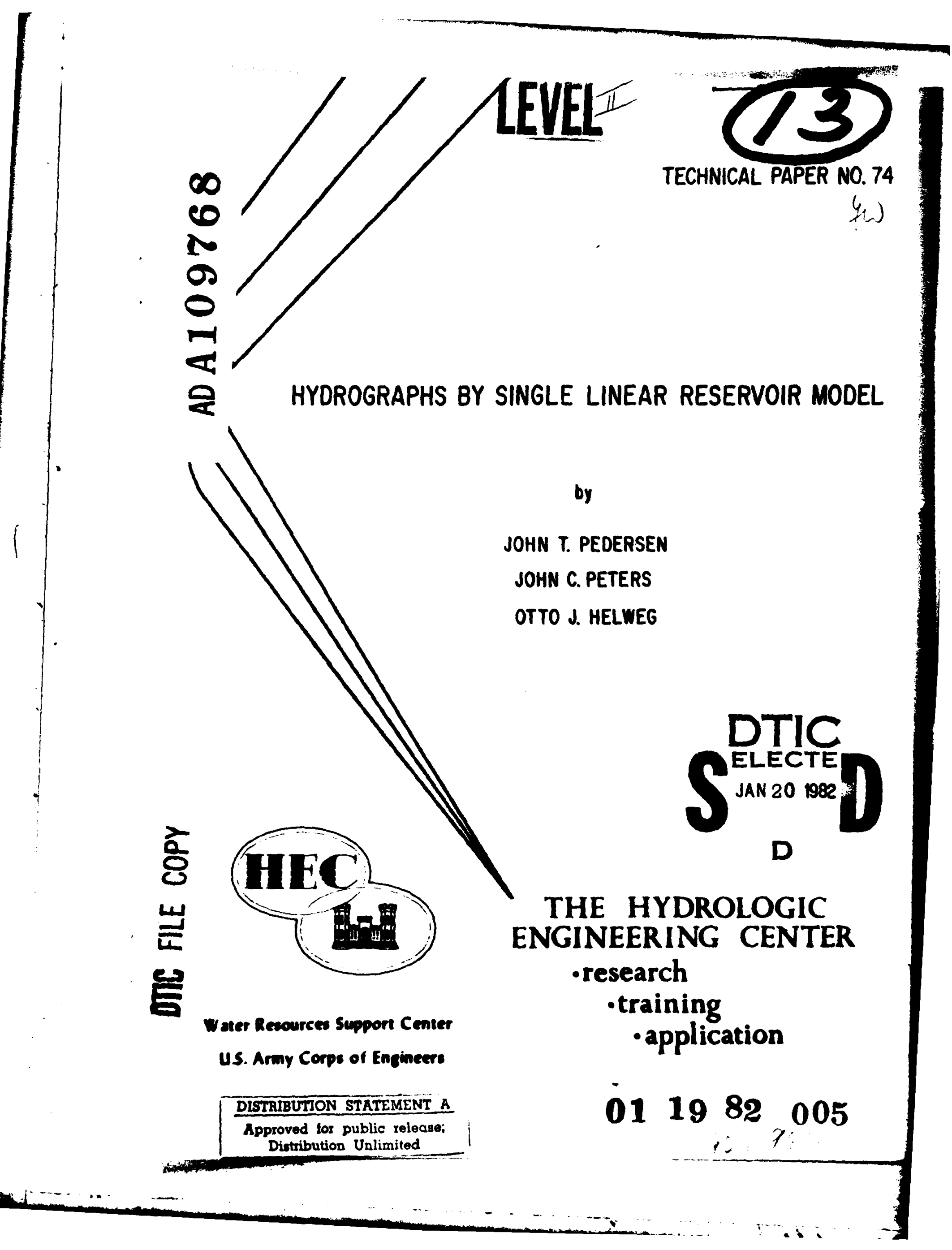


UNCLASSIFIED

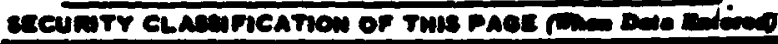

REPORT DOCOMENTATION PAEE

1. himont TuLLL

Technical Paper No. 74

Ai 1 109 768

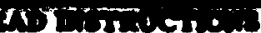

$x 000+2 \times 200$

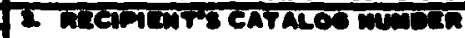

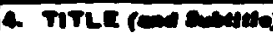

HYDROGRAPHS BY SINGLE LINEAR RESERVOIR MODEL

7. MUTMONa

John T. Pedersen, John C. Peters and

Otto J. Helweg

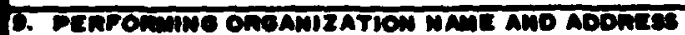

US Army Corps of Engineers

The Hydrologic Engineering Center (WRSC-HEC)

609 Second Street, Davis, CA 95616

ii. contnolline office wame AMD aDonces

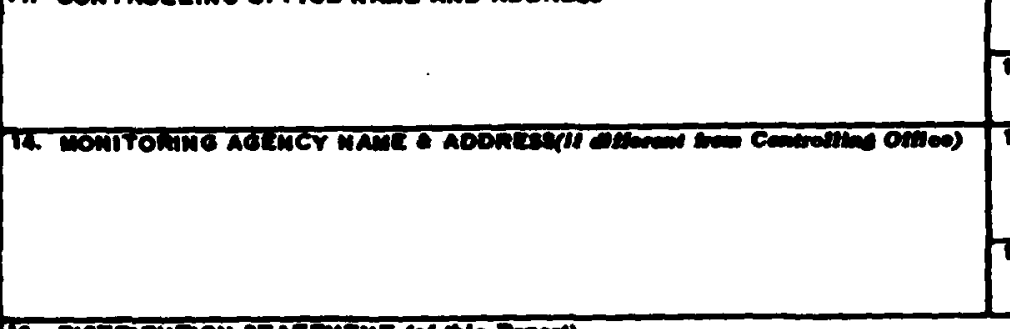

12. REPONT DATE MAY 80

1. Tre or menont a penod covento

16

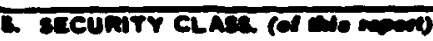

Distribution of this publication is unlimited.

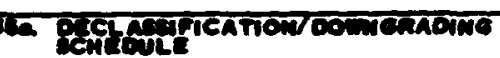

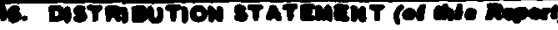

Accession For

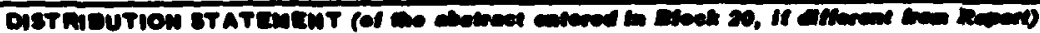

MIIS GRAkI

DTIC IAB

Unannounced

Just Ificatica

By-

Distris:ti $\cdots:$

- ivision:

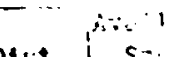

D1::2 $5: \ldots$.

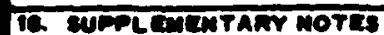

8

Published in Journal of the Hydraulics Division, ASCE, Vol, 106, No. HY5, Proc. Paper 15430, May, 1980, pp 837-852.

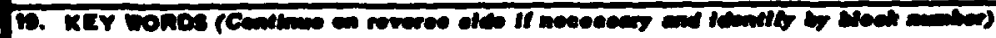

Hydrographs; mode1s; model studies; rainfall-runoff relationships;

storm water; urban areas.

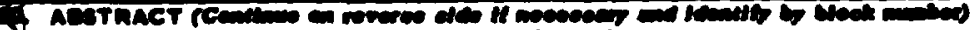

A single linear reservoir (SLR) model is presented which provides a simple means for developing runoff hydrographs for small, urban watersheds. The model only requires one parameter, $K$, which can be estimated from watershed and precipitation characteristics. Several methods for estimating $K$ and the results of testing the model on various watersheds are presented. 


\title{
Hydrographs by Single Linear RESERVOIR MODEL
}

\author{
By John T. Pedersen,' A. M. ASCE, John C. Peters," \\ and Otto J. Helweg, ${ }^{3}$ Members, ASCE
}

\section{InTRODUCTION}

The rainfall-runoff process is nonlinear and dynamic, with spatially distributed inputs and outputs. Because of the complexity of the runoff process and the absence of data with which to describe in detail the character of heterogenous watersheds and of spatially distributed inputs, simulation of the rainfall-runoff process is generally based on conceptual models. Such models contain parameters that must be estimated, and the models vary in complexity and in the range of runoff situations to which they apply.

The runoff transform mechanism that was investigated in the study described herein (9) is the single linear reservoir (SLR), which is intended for application in small watersheds with short response times. The model parameter, $K$, is related to watershed characteristics and to the intensity of effective rainfall. Results of application of the SLR model with experimental data and with data from actual watersheds are reported.

\section{Genenal Theony}

The single linear reservoir model transforms rainfall excess, determined outside of the model, to direct surface runoff as shown in Fig. I. The SL.R model is based on the concept that a watershed behaves as a reservoir in which storage $S$ is linearly related to outflow $Q$ by the equation

$S=K Q$.

Note.-Discussion open until October I, 1980. To extend the closing date one month. a written request must be filed with the Manager of Technical and Professional Publications, ASCE. This paper is part of the copyrighted Journal of the Hydraulics Division. Proceedings of the American Society of Civil Engineers, Vol. 106. No. HYS, May, 1980. Manuscript was submitted for review for possible publication on March 22. 1979.

'Hydraulic Engr., Hydrologic Engrg. Section. Los Angeles Dist., U.S. Army Corps of Engrs., Los Angeles, Calif.

'Hydraulic Engr., The Hydrologic Engrg. Center, U.S. Army Corps of Engrs.. Davis. Calif.

${ }^{3}$ Assoc. Prof., Dept. of Civ. Engrg., Univ. of California, Davis, Calif. 
The parameter $K$, called the storage coefficient, has the units of time, and is constant for a linear system. Basin storage at any time $t$ is equal to the
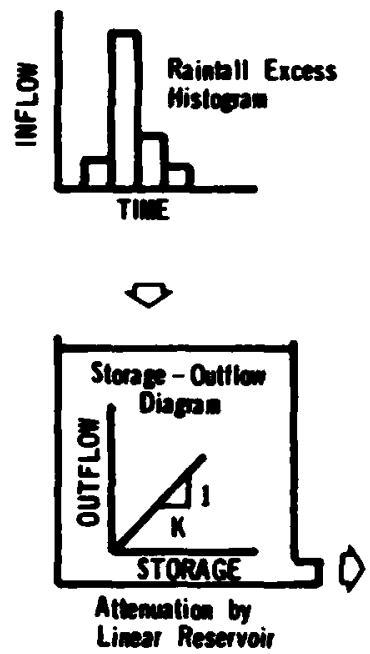

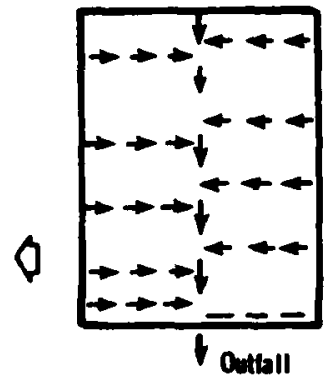

Concentual Walersived

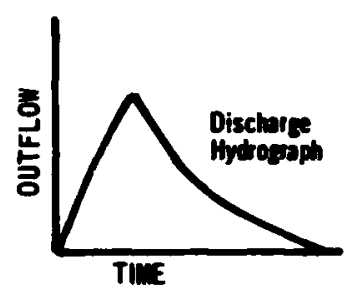

F16. 1. - SLA Concoptual Modol

summation of rainfall excess minus the volume of outflow up to time $t$. Combining Eq. I with the hydrologic continuity equation

$I-Q=\frac{d S}{d t}$.

yields the linear differential equation

$I-Q=K \frac{d Q}{d t}$

in which $I=$ inflow (rainfall excess) at any time $t$. Integration of Eq. 3, using the initial condition that $Q=0$ when $t=0$, results in the equation

$Q(t)=I(t)\left(I-e^{-t / k}\right)$

If rainfall excess ceases at time $T_{R}$ after beginning of outflow, and if $Q^{*}$ is the outhow at time $T_{n}$, then Eq. 3 becomes

$-Q=K \frac{d Q}{d t^{\prime}}$

in which $t^{\prime}=t-t_{n}$. Integration of Eq. 5 , subject to the condition that $Q$ $=Q^{*}$ when $t^{\prime}=0$, yields

$Q\left(t^{\prime}\right)=Q \cdot e^{-0^{\prime} / x}$ 
It can be seen that Eqs. 4 and 6 define the rising and falling limbs, respectively. of a hydrograph.

For an inflow, $I$, that fills the reservoir of storage, $S *$, instantaneously $\left(T_{k}\right.$ $=0$ ), combining Eq. 6 with Eq. 1 results in the equation

$$
Q(t)=\frac{S^{*}}{K} e^{-1 / x}
$$

and for a unit inflow or unit storage, the instantaneous unit hydrograph (IUH) is given by

$h(t)=\frac{1}{K} e^{-\cdot 1 / x}$

in which $h(t)=$ the IUH ordinate. A unit hydrograph of duration $\Delta t$ can be calculated by Eqs. 4 and 6 for a unit inflow 1 . Approximately the same result

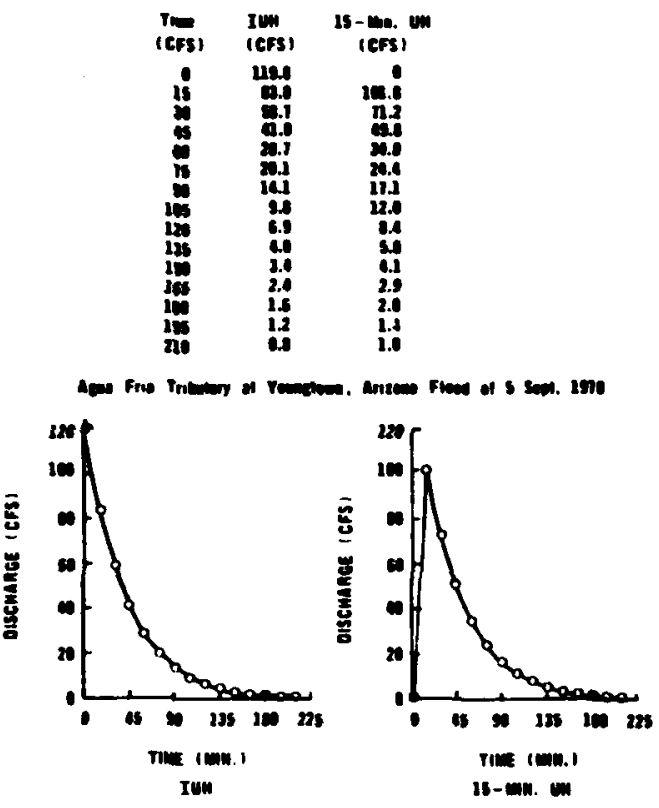

FIG. 2.-Typical SLR Unit Hydrographs

is obtained by averaging IUH ordinates $\Delta t$ units apart, if the initial ordinate of the $\Delta t$ unit hydrograph is set equal to zero as required by Eq. 4 (see Fig. 2), and $\Delta t$ is sufficiently small to provide reasonable definition of the unit hydrograph.

Eq. 2 can also be expressed in finite-difference form as

$\frac{\left(I_{1}+I_{2}\right)}{2}-\frac{\left(Q_{1}+Q_{2}\right)}{2}=\frac{S_{2}-S_{1}}{\Delta t}$.

in which subscripts 1 and 2 refer to beginning and end, respectively, of an interval $\Delta r$. Thus, combining Eq. I with Eq. 9 
$\frac{\left(I_{1}+I_{2}\right)}{2}-\frac{\left(Q_{1}+Q_{2}\right)}{2}=\frac{K}{\Delta t}\left(Q_{2}-Q_{1}\right) \ldots \ldots \ldots$

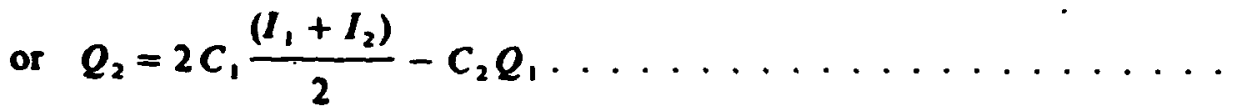

in which $c_{1}=\frac{\Delta t}{2 K+\Delta t} \ldots \ldots \ldots \ldots$

$c_{2}=\frac{2 K-\Delta t}{2 K+\Delta t} \ldots \ldots \ldots \ldots \ldots \ldots \ldots \ldots \ldots \ldots \ldots \ldots \ldots \ldots \ldots \ldots$

Eq. 11 requires the average inflow for the interval $\Delta t$. Since the excess rainfall hyetograph is normally in histogram form (that is, in terms of average ordinates), the time interval $\Delta l$ is chosen to coincide with the hyetograph ordinates. Thus $I_{1}=I_{2}$, and Eq. 11 becomes

$Q_{2}=2 C_{1} I_{2}+C_{2} Q_{1} \ldots \ldots \ldots \ldots \ldots$

Eqs. 12-14 are the "working" equations of the SLR model.

If $I_{2}$ in Eq. 14 is a unit inflow with duration $\Delta l$, the resulting unit hydrograph would be essentially identical to that obtained by averaging IUH ordinates based on Eq. 8 and much easier to compute (6).

The SLR model, then, can be viewed as a one-parameter unit hydrograph model with the special characteristic of always peaking $\Delta t$ time units after the beginning of rainfall excess. This is a limitation that restricts the use of the model to watersheds that are relatively small and "flashy." However, many urban watersheds fit this classification, especially those with extensive, effective storm sewer systems. If a watershed is divided into subcatchments, the unit hydrograph limitation may be alleviated at the expense of a requirement for accurate definition of channel routing parameters.

\section{Detenamanation of $K$}

The storage coefficient, $K$, has been shown to be equal to time lag $T_{L}$, defined as the time difference between centers of mass of rainfall excess and direct runoff (13).

Therefore $T_{L}=T_{0}-T_{1}=K$

in which $T_{1}=$ time interval from $t=0$ to centroid of inflow; and $T_{0}=$ time interval from $t=0$ to centroid of outflow.

For a particular storm event on a gaged watershed, $K$ can be estimated from rainfall excess and corresponding direct runoff,.provided: (1) The storms are relatively isolated in time; (2) they are fairly uniformly distributed over the waterahed; and (3) they have a single, well defined peak. If the excess rainfalldirect runoff process was actually linear, the value of $\boldsymbol{K}$ thus determined would be a constant for all storms. However, the variation of $K$ with rainfall characteristics has been established by various investigators $(11,13,14)$. Other than multiple regression techniques that generally produce relationships limited to a specific geographic region, how can $K$ be determined from measurable physical charac- 
teristics of a watershed and characteristics of the excess rainfall hyetograph?

Consider first the simple case of a planar surface and a constant effective rainfall intensity. Ref. 3 used kinematic wave theory to show that time to equilibrium, defined as the time required to reach steady-state conditions (inflow = outflow), can be expressed as

$t_{e}=\left(\frac{L i^{1-m}}{C}\right)^{1 / m}$

in which $t_{e}=$ time to equilibrium; $L=$ length of plane; $i=$ effective rainfall intensity; and $C, m=$ constants.

In Ref. 10 the following equations were developed assuming turbulent flow conditions. Here

$t_{e}=0.93 \frac{(L n)^{0.6}}{i^{0.4} S^{0.3}}$

in which $t_{e}=$ time to equilibrium, in minutes; $L=$ length of plane, in feet; $i=$ effective rainfall intensity, in inches per hour; $n=$ Manning's roughness coefficient; and $S=$ slope of planar surface, in feet per foot.

Defining basin lag, $t_{50}$, as the time difference between $50 \%$ of excess rainfall (equivalent to center of mass for a uniform rainfall) and $50 \%$ of the resulting direct runoff volume, Overton (7) used the kinematic wave equations to derive the expression

$t_{e}=1.6 t_{\text {so }}$

in which $t$, is defined by Eq. 17. Implicit in Eq. 18 is the relation

$t_{s 0}=\frac{s_{\mathrm{eq}}}{i}$

in which $S_{\infty}=$ storage at equilibrium; and $i=$ constant effective rainfall intensity. Overton (6) developed Eq. 19 from the geometry of a conceptual equilibrium hydrograph (see Fig. 3). However in testing Eq. 19 on data obtained by the U.S. Corps of Engineers experimental program (18) it was found that the ratio of $t$. (calculated by Eqs. 18 and 19) to 1. determined by Eq. 17 was about 0.8. If $S_{e q} / i$ is set equal to $T_{L}$, then

$t_{e}=2 T_{L}$

which is consistent with the Corps data. In other words, $t_{s 0}$ is about $0.8 T_{L}$. The same ratio can be deduced from experimental data given in the study conducted by Pabst (8). Using the relationships defined by Eqs. 15 and 20, Eqs. 12 and 13 become, respectively

$C_{1}=\frac{\Delta t}{t_{e}+\Delta t}$

and $c_{2}=\frac{t_{e}-\Delta t}{t_{e}+\Delta t}$

in which 1 , is defined by Eq. 17. 
Eqs. 15 and 20 can be combined with Eq. 17 yielding

$$
K=\frac{0.93(L n)^{0.6}}{2 i^{0.4} s^{0.3}} \ldots \ldots \ldots \ldots \ldots \ldots \ldots \ldots \ldots \ldots \ldots \ldots \ldots \ldots \ldots \ldots \ldots
$$

Eq. 23, then, provides a method for estimating $K$ from physical and storm characteristics for a planar surface and a constant effective rainfall intensity. Length of plane, slope, and rainfall intensity are easily established. Manning's $n$ value, perhaps better described as a roughness index, must be determined experimentally for artificial surfaces, such as simulated turf. For concrete and certain other common surfaces, $n$ values may be obtained from standard references

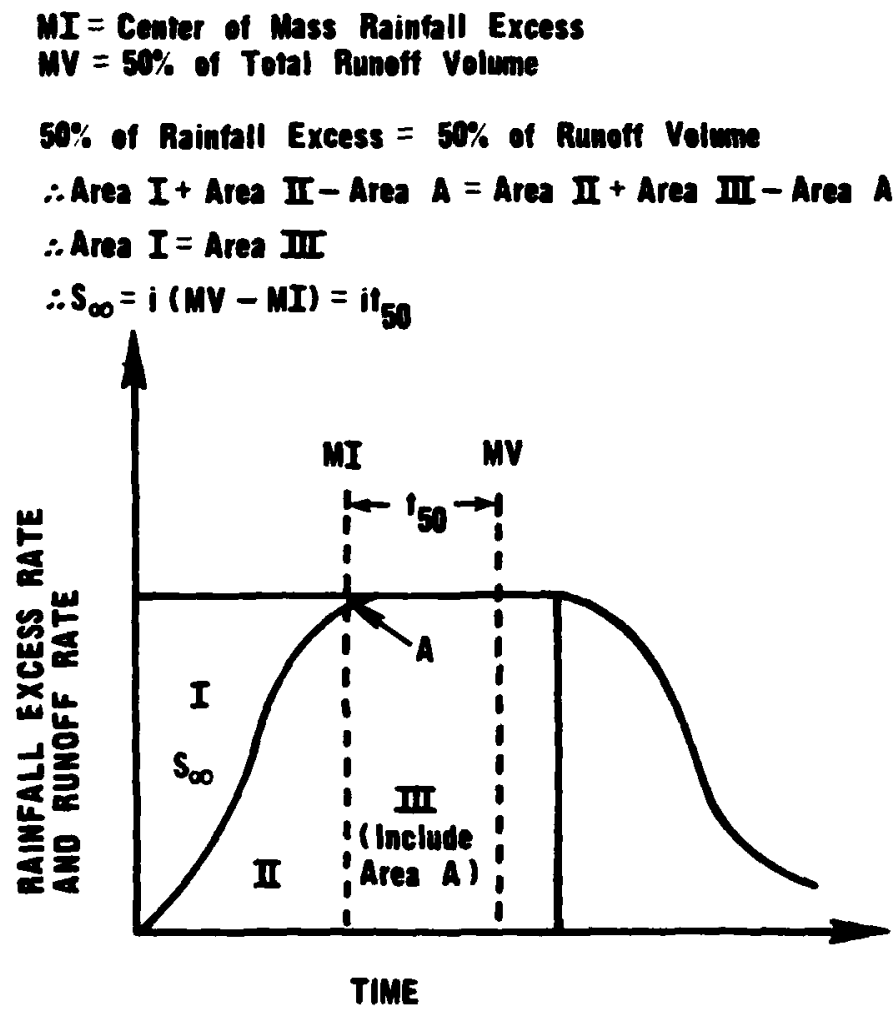

FIG. 3.-Theorotical Equilibrium Hydrograph

(1). Overland flow $n$ values should be distinguished, however, from open channel values.

To be generally useful, application of Eq. 23 must be extended to more complicated situations, such as an actual storm on a complex urban basin. The question naturally arises as to the validity of such extrapolation. This study assumed that a small watershed could be adequately represented as a planar surface and that the appropriate value of $i$ in Eq. 23 was the maximum $\Delta t$-minute effective rainfall intensity, in which $\Delta t$ is the computation interval chosen to provide reasonable definition of the unit hydrograph. Representation of a catchment as a planar surface is a common assumption in models that use kinematic routing to define overland flow, such as the Storm Water Management 
Model (15). If necessary, a basin can be subdivided so as to better approximate planar surfaces. In the small watersheds where the SLR model is applicable. most storms of interest, including design storms, are characterized by a short. relatively high-intensity burst of rain which causes the peak discharge to occur. Thus, it was reasoned that the maximum effective rainfall intensity of duration equal to the computation interval $\Delta t$ would be the appropriate value of $i$ in Eq. 23.

Representative values of length, slope, and roughness index will vary in an urban basin depending on both the existence of an effective storm drain system and on the severity of the storm being considered. Three extreme situations can be envisioned. First, if relatively light rain falls in a basin with no storm drain system, runoff would be conveyed to the basin outlet by streets and

TABLE 1.-Watershed Characteristics

\begin{tabular}{|c|c|c|c|c|c|c|c|c|}
\hline $\begin{array}{c}\text { Number } \\
\text { (1) }\end{array}$ & $\begin{array}{l}\text { Watershed } \\
\text { (2) }\end{array}$ & $\begin{array}{c}\text { Area, } \\
\text { in } \\
\text { square } \\
\text { miles } \\
\text { (square } \\
\text { kilo- } \\
\text { meters) } \\
\text { (3) }\end{array}$ & $\begin{array}{l}\text { Length. } \\
\text { in } \\
\text { miles } \\
\text { (kilo- } \\
\text { meters) } \\
\text { (4) }\end{array}$ & $\begin{array}{l}\text { Slope. } \\
\text { in } \\
\text { foet } \\
\text { per } \\
\text { foot } \\
\text { (5) }\end{array}$ & $\begin{array}{l}\text { Imper- } \\
\text { vious } \\
\text { cover, } \\
\text { as a } \\
\text { per- } \\
\text { cent- } \\
\text { age } \\
(6)\end{array}$ & $\begin{array}{c}n- \\
\text { value } \\
\text { used } \\
(7)\end{array}$ & $\begin{array}{c}\text { Source } \\
\text { of } \\
\text { data } \\
(8)\end{array}$ & $\begin{array}{c}\text { Number } \\
\text { of } \\
\text { storms } \\
\text { studied } \\
(9)\end{array}$ \\
\hline 1 & $\begin{array}{l}\text { El Modena-Irvine Chan- } \\
\text { nel at Myford Road. } \\
\text { Orange County. Calif. }\end{array}$ & $\begin{array}{r}11.9 \\
(30.9)\end{array}$ & $\begin{array}{c}6.35 \\
(10.22)\end{array}$ & 0.0098 & 40 & 0.02 & (12) & I \\
\hline 2 & $\begin{array}{l}\text { Agua Fria Tributary at } \\
\text { Youngtown. Ariz. }\end{array}$ & $\begin{array}{c}0.13 \\
(0.34)\end{array}$ & $\begin{array}{l}0.76 \\
(1.22)\end{array}$ & 0.0030 & 25 & 0.03 & $\begin{array}{l}\text { (3) } \\
\text { USGS }\end{array}$ & 2 \\
\hline 3 & $\begin{array}{l}\text { Waller Creek at 38th } \\
\text { Street, Austin. Tex. }\end{array}$ & $\begin{array}{l}2.31 \\
(6.0)\end{array}$ & $\begin{array}{l}4.37 \\
(7.04)\end{array}$ & 0.0089 & 27 & 0.025 & (13) & 3 \\
\hline 4 & $\begin{array}{l}\text { Victoria Street Storm } \\
\text { Drain, Santa Barbara, } \\
\text { Calif. }\end{array}$ & $\begin{array}{r}0.61 \\
(1.6)\end{array}$ & $\begin{array}{l}2.18 \\
(3.51)\end{array}$ & 0.0609 & 22 & & $(16.17)$ & \\
\hline 5 & $\begin{array}{l}\text { I7th Street Storm Drain. } \\
\text { Louisville, Ky. }\end{array}$ & $\begin{array}{c}0.22 \\
(0.57)\end{array}$ & $\begin{array}{l}0.42^{*} \\
(0.68)\end{array}$ & $0.0038^{t h}$ & 44 & 0.019 & (2) & 2 \\
\hline \multicolumn{9}{|c|}{$\begin{array}{l}\text { "Mean travel distance. } \\
\text { "Mean sewer slope. } \\
\text { Note: } \mathrm{I} \mathrm{ft}=0.305 \mathrm{~m}\end{array}$} \\
\hline
\end{tabular}

other hydraulically connected impervious areas. In this case, a representative length of flow path and basin slope can be estimated from topographic maps. The appropriate roughness index or $n$ value would depend on the type of surfaces comprising the impervious areas.

A second situation is that of a relatively light rain falling in a highly sewered basin. Under these circumstances, length, slope, and roughness index would be based on sewer system characteristics rather than basin characteristics, assuming that the "inlet" time is small compared with the travel time in the storm drain. An alternative to Eq. 23 in this case is the procedure suggested by Stubchaer $(16,17)$. Storage coefficient, $K$, was set equal to the travel time through the basin, calculated by summing the initial (overland flow) time, street travel time. and storm drain travel time. Initial times were estimated from 
nomographs. Flow times, other than initial times, were computed from the shallow triangular channel equation

$Q=0.56\left(\frac{Z}{n}\right) s^{1 / 2} Y^{n / 3} \ldots \ldots \ldots \ldots \ldots$

The parameters in Eq. 24 have the same meaning as in Manning's equation. Parameter $Z$ is the channel side slope. The value of $n$ was assumed to be

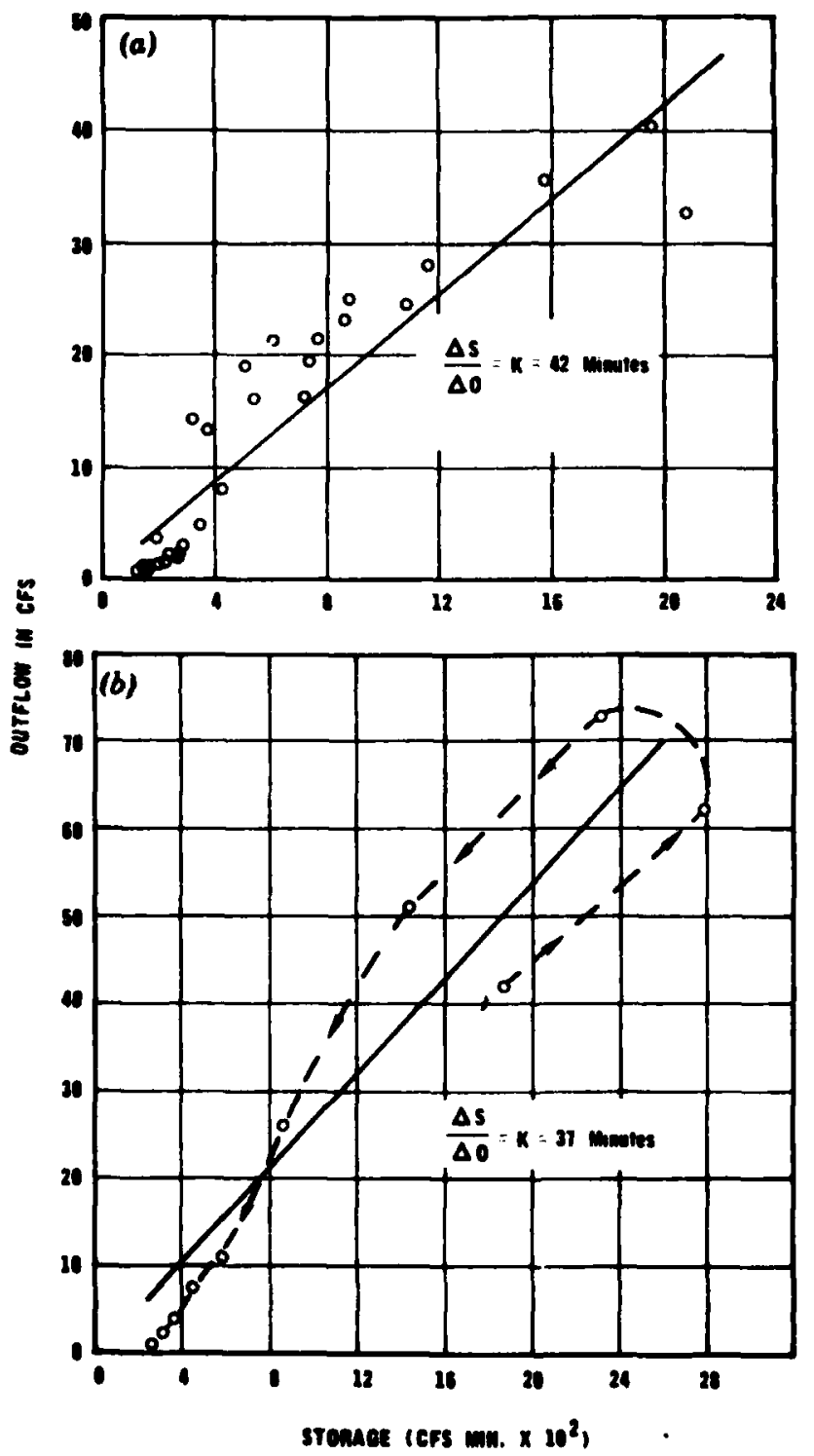

F10. 4.-Storage-Outtiow Loop, Agua Fria Tributary at Youngtown, Ariz., Flood of: (b) Sopt. 5. 1970. (b) Oet. 16. 1964

0.015. To use Eq. 24 on depth must be assumed; factors $S$ and $Z$ can be measured. - se actual sewer flow velocity, thus travel time, of a sewer running between one-half and full capacity varies between narrow limits, but to consider the 
velocity constant requires an implicit assumption that the computed hydrograph is not sensitive to small changes in $K$.

A third situation would occur when a very severe storm is being considered. such as is required for flood insurance studies, for example. Most urban storm drain systems would likely be greatly overtaxed, with a major portion of the runoff proceeding to the basin outlet as overland flow. Although similar to the first situation described previously, here the streets have insufficient capacity

TABLE 2.-Storage Coefficients. $K$

\begin{tabular}{l|c|c|c}
\hline $\begin{array}{c}\text { Watershed } \\
(1)\end{array}$ & $\begin{array}{c}\text { Storm } \\
(2)\end{array}$ & $\begin{array}{c}\text { Measured } K, \\
\text { in minutes } \\
(3)\end{array}$ & $\begin{array}{c}\text { Computed } K . \\
\text { in minutes } \\
(4)\end{array}$ \\
\hline El Modena-Irvine channel & & & \\
at Myford Road & $2 / 25 / 69$ & 135 & 139 \\
Agua Fria tributary at Youngtown & $10 / 16 / 64$ & 33 & 37 \\
17th Street storm drain & $9 / 05 / 70$ & 38 & 42 \\
& $8 / 06 / 47$ & 17 & 20 \\
\hline
\end{tabular}

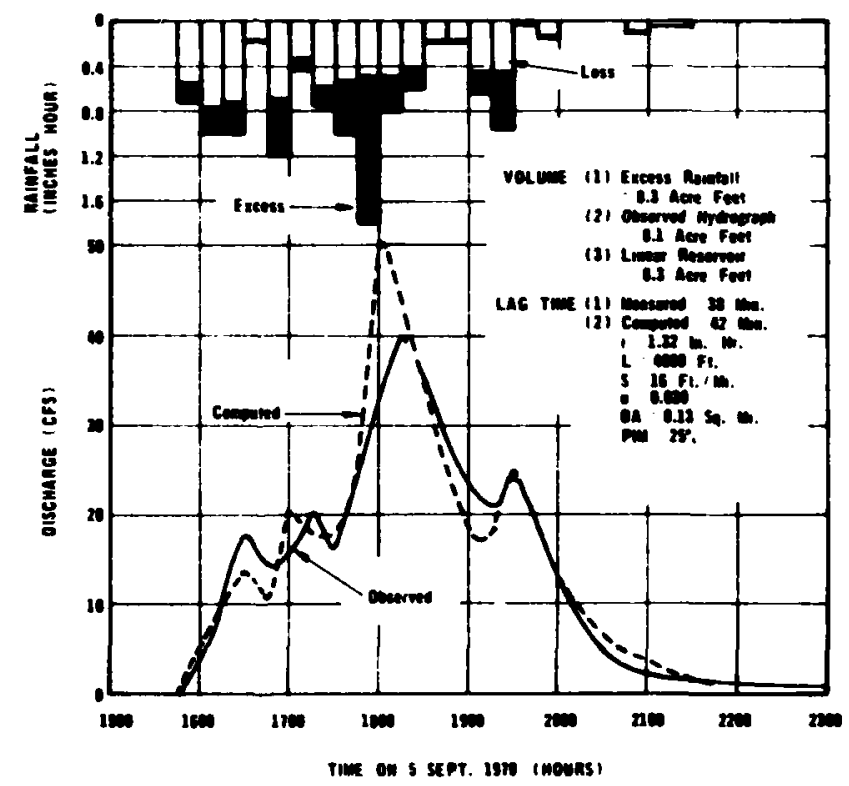

FIG. 5.-Reconstitution, Ague Fris Tributery at Youngtown, Ariz., Flood of Sept. 5,1970

to carry the total flow. The result is a lower average flow velocity and longer travel times. accounted for in Eq. 23 by increasing the $n$ value. Due to the large flow. the length of flow path may change, and ponding may also have to be considered.

It can be seen, then, that considerable engineering judgment must be exercised when using Eq. 23 in a complex urban situation. The same type of judgment. however, is necessary when using virtually any of the available models. 


\section{Model Vemacation}

Two classes of data were used to verify the SLR model. The first class was data from an experimental program conducted by the Los Angeles District.

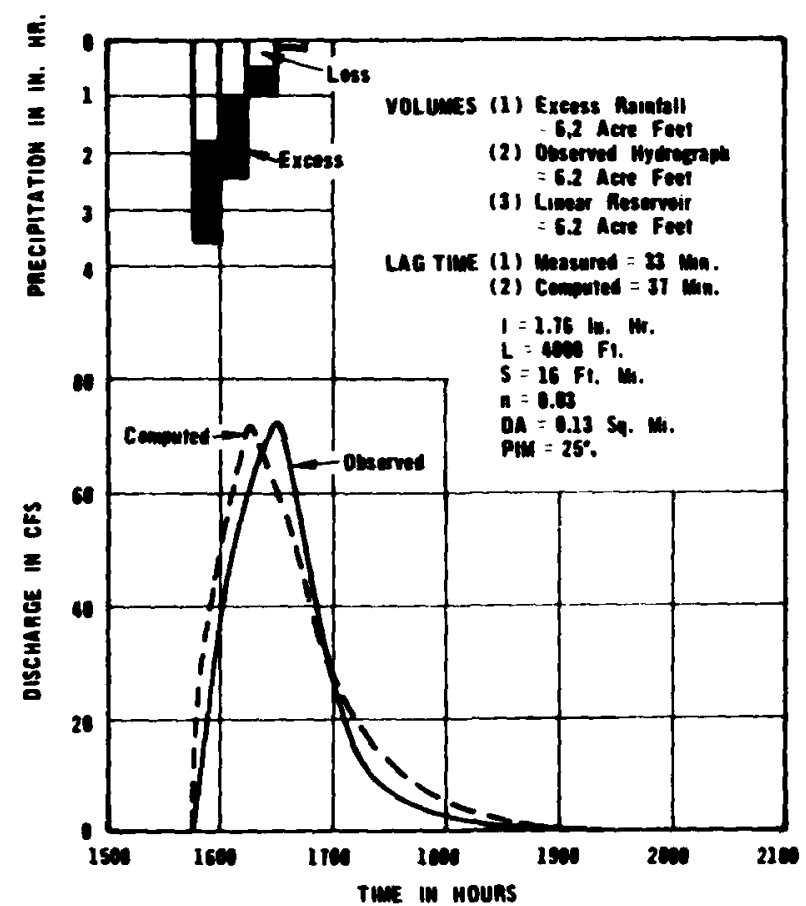

FIG. 6.-Reconstitution, Ague Fria Tributary at Youngtown, Ariz., Flood of Oct. 16. 1964

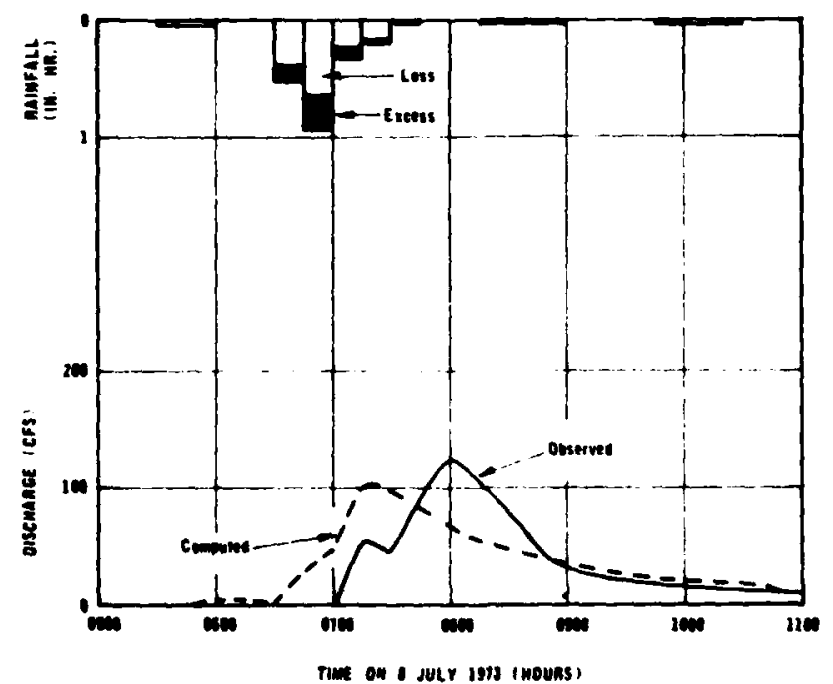

F1G. 7.-Reconstitution, Wallor Creak at 38th St., Flood of July 8, 1973, 1200-1900

U.S. Army Corps of Engineers (18) in which different combinations of rainfall intensity and basin characteristics were simulated on a physical model. The 
results of these simuiations agreed closely with the SLK mooei and are cocumented in Ref. 9.

The second class of data was extracted from available engineering literature except for the Oct. 16, 1964 storm event on the Agua Fria Tributary watershed. which was obtained from the United States Geological Survey. These data having been collected from actual watersheds are of more interest. though only two of the five watersheds listed in Table $I$ are included in this paper. Again. Ref. 9 gives the results of all five.

The four sets of data included in this paper comprise the worst case, the best case, and two "average" cases. The watersheds used were the Agua Fria, Waller Creek, and 17th Street Storm drain. Their characteristics are examined in the following paragraphs.

The 0.13-sq mile $\left(0.34-\mathrm{km}^{2}\right)$ Agua Fria Tributary catchment in Youngtown, Ariz. is a small, flat, residential area drained by street flow. It is nearly rectangular

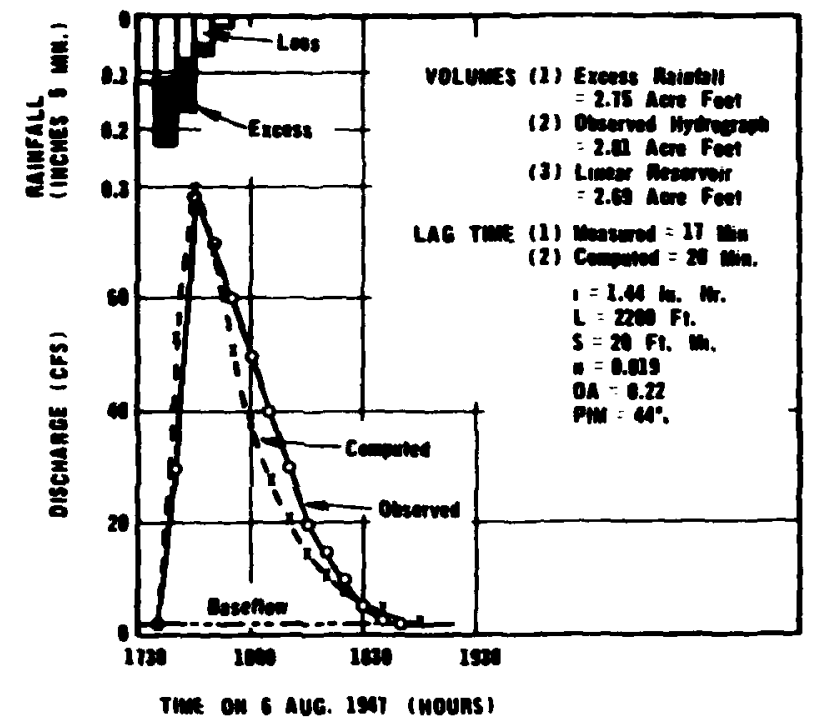

FG. 8. - Reconstitution, 17th Streot Storm Drain, Flood of Aug. 6. 1947

in shape, with streets running essentially parallel to the watershed boundaries. Hydraulically connected impervious cover was estimated from field inspection to be $25 \%$.

The 2.31-sq mile $\left(6-\mathrm{km}^{2}\right)$ Waller Creek watershed lies entirely within the City of Austin, Tex., with headwaters originating in the northern part of the city. A storm drain system exists within the basin (details not readily available). Hydraulically connected impervious cover was estimated to be $27 \%$ (13). Ratios of runoff to rainfall for the storm used in this study confirm this figure.

The 0.22-sq mile $\left(0.57-\mathrm{km}^{2}\right) 17$ th Street basin is one of a number of highly urbanized, small drainage areas in Louisville, $\mathrm{Ky}$. included in an extensive program of measurement and analysis of hydrographs of storm sewer flow carried out by the Louisville District of the U.S. Army Corps of Engineers during the years 1945-1949. The watershed was estimated to be $83 \%$ impervious, with a total runoff to total rainfall ratio for small storms of $44 \%$ (2). 
Evidence of both the nonlinearity of the runoff process and the appropriateness of the relationship for $K$ in the model can be seen by constructing the storage-outhow loops shown in Figs. $4(a)$ and $4(b)$. The loops were constructed by plotting observed end of period outflow versus end of period storage calculated by Eq. 9. The coefficient $K$ is equal to the ratio of the change in storage $\Delta S$ to the change in outflow $\Delta Q$. For a good portion of the various loops, $\Delta S / \Delta Q$ very closely approximates $K$, as computed by Eq. 23. In other parts of the loops, $K$ is obviously a poor representation of the slope of the storageoutflow relationship. Similar loops are shown in the study in Ref. 13.

Of the watersheds studied, the most valuable flood events satisfied the following

TABLE 3.-Sonsitivity of $K$

\begin{tabular}{c|c|c}
\hline \hline $\begin{array}{c}\text { Parameter in Eq. 32 } \\
\text { (1) }\end{array}$ & $\begin{array}{c}\text { Change in parameter, } \\
\text { as a percentage } \\
(2)\end{array}$ & $\begin{array}{c}\text { Change in } K . \\
\text { as a percentage } \\
(3)\end{array}$ \\
\hline$L$ & +20 & +12 \\
$n$ & +20 & +12 \\
$S$ & +20 & -8 \\
$S$ & +20 & -6 \\
\hline
\end{tabular}

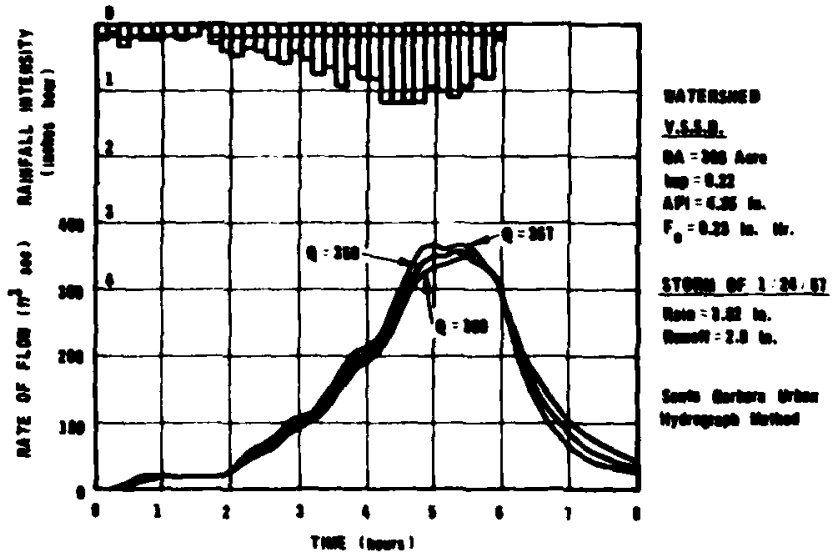

FIG. 9. Effects of $20 \%$ Chango in $K$ for Short, Intonse Storm

criteria: (1) Storms were relatively isolated in time (i.e., were preceded and followed by dry periods); (2) storms exhibited approximately uniform spatial distribution over the entire watershed; and (3) runoff hydrographs had a single, well defined peak followed by unsustained recession. The loss functions and base flow separation techniques used in the referenced data source were also used in this study. Although not treated rigorously herein, the determination of accurate loss and base flow rates are nevertheless important, especially when comparing measured lag times with computed values. If the storm being considered is small, however, the influence of losses and base flow is negligible, as most runoff would come from impervious areas.

For several events that exhibited a single predominant peak, lag times $T_{L}$ 
were determined by taking moments of rainfall excess and direct runoff about a time line, say $t=0$. These "measured" values of $T_{L}$ are listed in Table 2 , together with calculated $K$ values. The maximum difference is about $18 \%$.

The validity of any hydrologic model is best tested by the model's ability to reproduce observed events. Data obtained from the experimental program conducted by the U.S. Corps of Engineers (18) comes closest to matching conditions assumed in the derivation of Eq. 25; however, as stated previously

TABLE 4.-Effect of $20 \%$ Change in $K$ on Paak Flows for Vietoria Street Storm Drain"

\begin{tabular}{c|c|c|c}
\hline \hline $\begin{array}{c}\text { Storm } \\
(1)\end{array}$ & $t(c)$, in hours \\
$(2)$ & $\begin{array}{c}\text { Peak flow, in cubic } \\
\text { feet per second } \\
(3)\end{array}$ & $\begin{array}{c}\text { Difference } \\
(4)\end{array}$ \\
\hline 1958 & 0.48 & 549 & $+15.3 \%$ \\
& 0.60 & 476 & - \\
1967 & 0.72 & 422 & $-11.3 \%$ \\
& 0.48 & 367 & $+2.2 \%$ \\
& 0.60 & 359 & - \\
\hline
\end{tabular}

'From Ref. 17.

Note: $1 \mathrm{cfs}=28 \mathrm{~L} / \mathrm{sec}$.

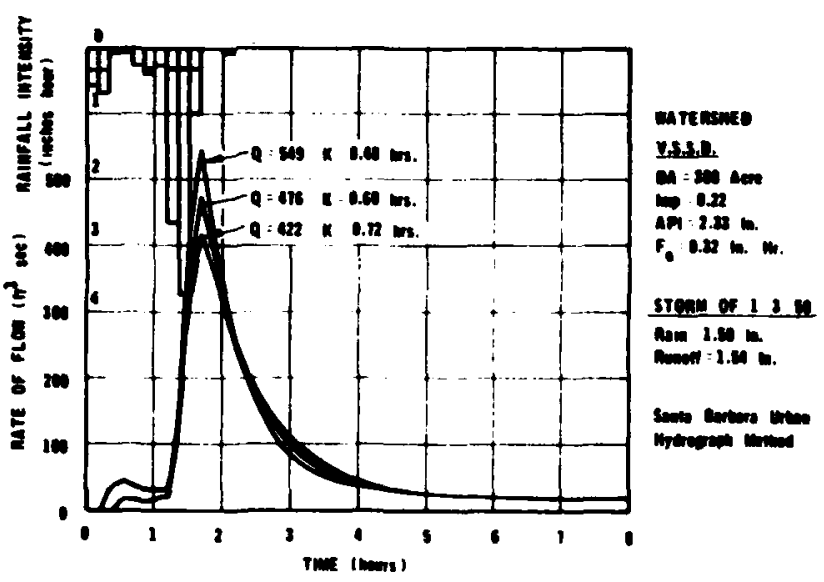

FIG. 10. Effocts of $20 \%$ Change in $X$ for Long, Stoady Storm

only the reconstitutions of observed flood events in actual urban basins are shown in Figs. 5-8. The maximum difference in peak is about $20 \%$ for catchments other than Waller Creek; most reproduced peaks are within 5\% of the observed peak. Perhaps coincidentally, the time difference between computed and observed peaks is often approximately equal to $K / 2$. Studying other storms on Waller Creek indicate that the generally unsatisfactory reproductions typified by Fig. 7 are probably caused by nonuniform rainfall distribution over the basin during these storm events. 


\section{Semertuvir or Panametens}

The impact on $K$ of varying the parameters in Eq. 23 is shown in Table 3. Increasing each parameter, in turn, by $20 \%$ changes $K$ by $6 \%-12 \%$. However, the effect on the calculated peak flow of underestimating, or overestimating $K$ is dependent on the distribution of effective rainfall $(16,17)$. Figs. 9 and 10 show that for a high intensity, short duration storm, the effect can be quite pronounced. In this case, routing through the watershed had a significant impact. As can be seen in Table 4, the same variation in $K$ had little effect on a longer duration, less intense storm. Runoff rates were nearer equilibrium, and routing was not so important. In the course of an unpublished Los Angeles District, Corps of Engineers study using the SLR model, $n$ values were changed as much as $90 \%$, with a resultant change in peak of about $25 \%$.

\section{Conctusuons}

Use of Eq. 23 is a deviation from traditional unit hydrograph theory in that unit hydrograph parameters are usually considered to be independent of storm characteristics. However, it is well known that unit hydrographs for a particular basin do vary from storm to storm, and sufficient evidence exists to establish the variability of $K$ with rainfall characteristics. Thus, the model used in this study could be thought of as a quasilinear model. The transformation of rainfall excess to direct runoff is accomplished by a linear system model, but, instead of using a unique response function applicable to a basin, the response function is redefined for each storm event.

Because the SLR model unit hydrograph always peaks $\Delta t$ time units (equal to the computation interval) after beginning of rainfall excess, use of the model is restricted to small, "flashy" watersheds.

\section{ACKMOMnEDGMENTS}

The senior writer wishes to express thanks to the U.S. Army Corps of Engineers for supporting this study.

\section{Appendox 1.-Refenences}

1. Chow, V. T., Open-Channel Hydraulics, McGraw-Hill Book Co., Inc., New York, N.Y., 1959.

2. Eagleson, P. S., "Unit Hydrograph Characteristics for Sewered Areas," Journal of the Hydraulics Division, ASCE, Vol. 88, No. HY2, Proc. Paper 3069, Mar., 1962, pp. I-25.

3. "Gila River Basin, New River and Phoenix City Streams, Arizona," Design Memorandum No. 2, Hydrology. Part I, United States Army Corps of Engineers, Los Angeles District. Calif., Oct.. 1974.

4. Henderson, F. M.. and Wooding, R. A.. "Overland Flow and Groundwater Flow from a Steady Rainfall of Finite Duration," Journal of Geophysical Research, Vol. 69, No. 8, Apr., 1964.

5. Mitchell, R. N., "Hydrologic Data for Urban Studies in the Austin. Texas Metropolitan Area. 1973." U.S. Geological Survey Open File Report, May. 1975.

6. Overton. D. E.. "Route or Convolute?" Water Resources Research, Vol. 6. No. I. Feb.. 1970, pp. 43-52. 
7. Overton. D. E.. and Meadows. M. E.. Stormwater Modeling. Academic Press. New York. N.Y.. 1976.

8. Pabst, A. F.. "Hydrograph Linearity in an Elementary Channel." thesis presented to the University of Minnesota. at Minneapolis. Minn.. in 1966. in partial fulfillment of the requirements for the degree of Master of Science.

9. Pedersen. J. T.. "Runoff Simulation by the Single Linear Reservoir Model." thesis presented to the University of California, at Davis, Ca., in 1978, in partial fulfillment of the requirements for the degree of Master of Science.

10. Ragan, R. M., and Duru, J. O., "Kinematic Wave Nomograph for Times of Concentration." Journal of the Hydraulics Division, ASCE. Vol. 98. No. HY10. Proc. Paper 9275. Oct.. 1972. pp. 1765-1771.

11. Rao, R. A.. Delleur. J. W., and Sarma. P. B. S., "Conceptual Hydrologic Models for Urbanizing Basins," Journal of the Hydraulics Division. ASCE. Vol. 92. No. HY7, Proc. Paper 9024. July, 1972, pp. 1205-1220.

12. "Review Report on the Santa Ana River Main Stem-Including Santiago Creek and Oak Street Drain," Appendix 2, Volume 2, Technical Information, United States Army Corps of Engineers, Los Angeles District, Calif., Dec., 1975.

13. Sarma, P. B. S., Delleur, J. W., and Rao. A. R.. "A Program in Urban Hydrology, Part II: An Evaluation of Rainfall-Runoff Models for Small Watersheds and the Efrects of Urbanization on Runoff," Purdue University Water Resource Research Technical Report No. 9. Purdue University, Lafayette. Ind., Oct., 1969.

14. Schulz, E. F., and Lopez, O. G.," Determination of Urban Response Time," Contract DACWOS-73-C-0029, Hydrologic Engineering Center. United States Army Corps of Engineers, July, 1974.

15. "Storm Water Management Model," Vol. I. Final Report. Metcalf and Eddy, Inc.. University of Florida, and Water Resources Engineers. Inc., for the Environmental Protection Agency, July, 1971.

16. Stubchaer, J. M.. "The Santa Barbara Urban Hydrograph Method," Proceedings of Engineering Workshop on Urban Hydrology. California State University, at Long Beach, Calif., Mar., 1975.

17. Stubchaer, J. M., "The Santa Barbara Urban Hydrograph Method," presented at the July, 28-31, 1975, National Symposium on Urban Hydrology and Sediment Control. held at the University of Kentucky, Lexington, Ky.

18. Yu, Y. S., and McNown, J. S., "Runoff from Impervious Surfaces," Contract Report No. 2-66. United States Army Engineer Waterways Experiment Station. Corps of Engineers, Vicksburg, Miss., Feb., 1963.

\section{Apeswoux II.-Notation}

The following symbols are used in this paper:

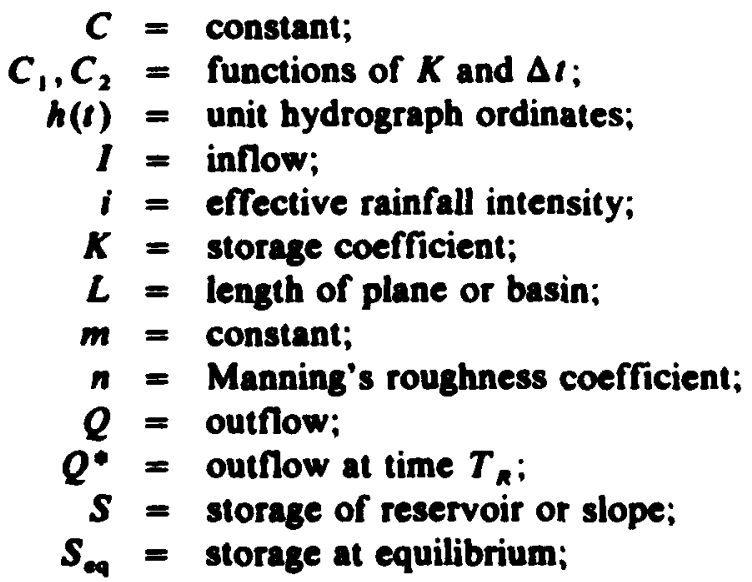


$T_{1}=$ time interval from $t=0$ to centroid of inflow;

$T_{L}=$ time lag;

$T_{0}=$ time interval from $t=0$ to centroid of outflow;

$T_{R}=$ time rainfall excess ceases;

$t_{c}=$ time to equilibrium;

$Y=$ depth of water in channel;

$Z$ = channel side slope; and

$\Delta t=$ time unit. 